\title{
FILAMENTOUS FUNGI FROM \\ AIDS PATIENT SECRETIONS AND FROM THE ENVIRONMENTAL AIR IN HOSPITAL
}

\author{
(Hongos filamentosos en secreciones de pacientes con SIDA \\ $y$ desde ol aire del ambiente hospitalario)
}

Rejane Pereira Nevesi, Lusinete Aciole de Queiror, Oliane M"C. Magalhães, Maria Auxiliadora de Q. Caralcanti, Maria José S. Fernandes, Dúbora M"M. Lima, Delson Laranjeira, Cristina $M^{2}$ de Souza-Motta

Departamento de Micologia, Centro de Cičncias Biológicas, Universidade Federal de Pernambuco, Recife, Pcrnambuco, Brasil.

Palabras clave: Hongos filancntosos, AIDS, micota nosocomial

Key words: Filamentous fungi, AIDS, nosocomial mycota

\section{RESUMEN}

Medionte la toma de muestras de secreciones orofaringeas, nasales y det oido externo de 50 pocientes con Sindrome de Imunodeficiencia Adquidida (SIDAAIDS) y del aire de las salas de tratamiento de los mismos, se obluwieron 238 muestras : 87 de las secreciones y 151 del aire. Se aistaron $29 \mathrm{spp}$. de hongos filamentosos de los especimenes clinicos y 38 del are. Lin las secreciones de los pacientes, el grapo forma: Mycelia sterilia, y Fustrium axysporum, Flateritium. Aspergillus parasificus, fteron los Thphombetes más representativs y los generos Aspergillas y Fusariam constiluveron el 47\% delos aistamientos en proporciones semejantes

En el ambiente hospitalario. el grupo forma Mycelia sterilia y los especies C. sphacrospermum, Aspergillus sydowii y C.chalosporioides fueron los Hyphonyceres más representaliwos y los géneros Aspergillus y Punicillium constimueron al $47,7 \%$ de los aislamientos. Los taxa más commines que se presentaron al mismo tiempo en los pacientes como en su ambicinte fueron:Myceliasterilia, C.sphaterospermun, A.sydowit, A.restrichus y Pinplicatum.

\section{INTRODUCTION}

The immmological alterations cxhibited by the ADS infected pationt, involve qualianive and quantiative defects in the T-lymphocyes with a consequent inbalance

\section{SUMMARY}

Samples from oropharyngeal, nasal and from the external ear secretions vere collected from 50 patients with the Acquired lmmune Deficiency Syndrome (ADS) and from the wards air in which they were begin treated. At tolat of 238 strains of filanentons fungi were obtained: 87 were clinical samples and 1.51 from the warls air: firom clinical samples were isolated 29 species and 38 of the warks air In the patient secretions, the form group Mycelia sterilia and Fusarium oxysporam, Filateritium, Aspergillus parasiticus, were the most representative Hyphomycetes, whereas genern Aspergillus and Fusarium represented $47 \%$ of isolations in similar proportions.

In the enwirommental air of the hospital, the form group Mycelia sterilia and Cladosporium. sphaerospermun, Aspergillas sydowii, C.cladosporioides, were the most representative Hyphomycetes, while the genera Aspergillus and Penicillium, represented $77,7 \%$ of isolations. Main taxa of fungi occurring at the same time both in patients and in the environmenal were:Mycelia steriliti, Cosphaterospermum, A.sydanit, A.restrictus and Pinplicatum.

in the immunological system lending to suppressive stimuli and the occurrence of opportunistic infections $(5,10,25$, $36,37,40)$.

Faclors whelher linked or not to host cxplain the large incidence of fungen infections, mainly in hospital enviromments, where nosocomial mycola is rich in fungi

I Part of the disscrtation for gellin a Muster's degree with support of Coordenação do Aperfeiçoamento de Nivel Supcrior (CAPES). 


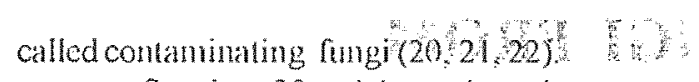

Specics of fungi donominacel as ancmophiles are responsible tor allergle conditions or for opportunistic mycosis, the latter being the min cause of morbidily and mortaliy of HIV infecled palicnts. These fungl have acquited in medical praclice a remarkable increasing importance in hospital cuvironments and in sevices where paticnis have bech kept with arious pathologics $(4.9,10$, $15.16 .17 .22 .23 .2+.27 .30 .33,35)$.

In the last decades the presence of fungi in the amospheric ain has been studicd more sirongly and is. an the homent, a thenc of greal importance since it is common both in allergic processes of the respiratory tracts and in infections by opportumistic agents in hospial cmiroments $(15,18,20,21,22,28,32)$.

In the atmospheric ar of the Depantment of Infections Pansitical Discase, University Hospinl, Center of Henllh Sciences. Federal Universily of Pcrmmbuco-" UFPE , there are watds in which AIDS paticnts were assisicd fortratmon.

Having in mind the occurrence of fungal infoclions in ADS paticuts and the viable fungal propagules in hospital environments, the objectives of this paper alre to isolite and idcntify fungi in ADS paticnt sccretions and from the emcrommental air in which they are being trealcd.

\section{MATERIAL AND METHODS}

Clinical samples were collected simultancously of orophangen, masal and from the extermal cal secretions of 50 ADS paticns: al the same time air samples from 7 wards in which these pilicnts wore being honted, were collected. The collections were developed dming 4 months from robnary $10 \mathrm{may} 1906$, al a $28^{\circ} \mathrm{C} \pm 1^{\circ} \mathrm{C}$ room temperiture, in the Infectious Pamsilical Discases Deparmen - DIP. University Hospital, Fedonal University of Pcmambuco, Recife Pcmambuco. Brazil.

The clinical samples were collected from patiens that had becn in Hospital at least for one wcek on fast with a sterilised swab which was transfered to a tube containing sterilised water which $50 \mathrm{mg}$ of chlororamphenicol/l. The wards air samples were collecled al threc cquidistam points by the aspirating hand acum lype microsyringe system, with a $13 \mathrm{~mm}$ Millipore membrine and 8 fm porc.

After collection both the clinical samples and the air samples were duly processed for direcl cxmmation (clinical smmples) and culture (clinical and air samples).

The dired cxammation of the clinical simples wis camicd out at room lemperature. charificd will aqueous solution at $20 \% \mathrm{KOH}$ and colourcd by the Gram and Gicmsa nellods.

To obtain culture from the clinical and air samples.
Sabourand agar was used to which $50 \mathrm{mg}$ of chloramphenicol/ and $5 \%$ of yeast cxtracl (XE) was added.

The clinicil samples vere sown in duplicate on the surface of the medium contaned on Petri dishes and minlancd a room temperatirc $\left(\mathrm{RT}=28^{\circ} \mathrm{C}+1-1^{\circ} \mathrm{C}\right)$.

To obtin culfuros from the air collcotions, the Millipore membrames were placed in $1 \mathrm{ml}$ of stcrilised distilled wather that was added $50 \mathrm{mg}$ of chlormphenicol contancd in test lubes and beaten in vortex. Both, suspensions and lie membranes were separalcly sown in duplicate on the sufface of the medium and mantaned at RT.

The developmen of the colonies was mantained for up 1020 difys. Aficr purificalion, the colonies were Iransforcd into Sabourud aga additioncd wilh $0,5 \% \mathrm{YE}$ conlaned in lube.

Identilication and classification or the rungi were madc by consuling Domschata. (11), Ellis (13,14), Nolson a al (26), Pill (29). Raper \& Fomel (31).

\section{RESULTSAND DISCUSSION}

A tolal of 238 strains of filamentous fungi: 87 clinical and 151 from the wards air samples vere obtained.

From clinical samples collecled of 50 AIDS pationts; 87 strains of filamentous fungi vere oblained, of which $69(77.53 \%$ were from masal. $17(19.19 \%)$ from the cxicmal car and $3(3,39 \%)$ from oropharyngal secrelions (Tuble 1).

In the patien sccretions the form group: Mycelia striha and Fusminn axyporam, Flaterithm, Aspergilhs parasiticus, were the most representive $H$ yhow mycefes, whoras goncri Aspergillus and Fusarium represcutcd $+7 \%$ of isolations in similar propontions.

Species of Abvilit, Aspergillas, Clabosploriam, Coprinus, Enpenichlium, Earotium, Fustrium, Pateilomices, Pentillinn, Pestalotiopsis, Phialopho-

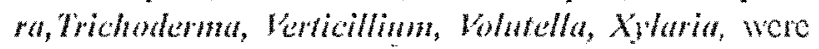
isolated as woll as representatives of llie order

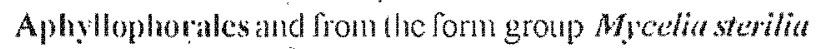
(Agonomyectales). Represcnlalives of the order Aphyllophorales, A. sydowiind the form group Myceta sterilia, occurred in the three byes of clinicul samples; Penicillinm implicatum occurred in nasil and exlcmal car secrolions; Phialophora richurdsiae in oropharyngeal sccretion; Aspergillus niger, A. purasiticus, A. restrictus, Whathatristis and A. versicolor occurred in the cxternal ear sccretion; the other species occurred only in nasal sccretion from which the grealest muber of fungi nere

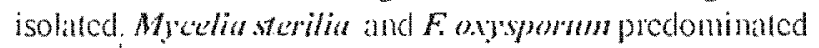
among the romining fungi (Tible i).

Allhough the recognition of mycosis infections is of the gratest importance, not only from the cpidemio- 
logical but also by the llempentic point of vion it is not alwals frequen that comact with the infecting agent of mycoric origin leids lo the appearance of mycosis discase (25).

On the olher hand. allergic processes antse from inhahation and ingestion of spores which induce varions manifestations such as a louking nose. rhimitis bronchial astluna or conjunctivitis (22).

In this paper the predominuce of fitmentous fungi isolated from masil secretion is supported by the results obutined by Choi (\$) will the sime types of clinical samples. The qumity and varicty of litmentons lungi isolated from masal secretom man be a result of the function of uostrils. acting as a matural litic of he respintory tacts.

Fusurim solumi, Foxpmom, F loteritum,

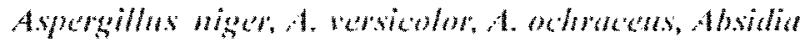

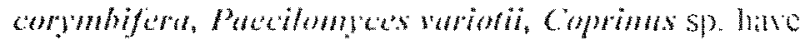
been reponted as a species of lingi which easily cilluses infirmity in the wetkened patients (2. 7.12.22.26.31.33. $3+.38,3 y)$.

One hundred and wenty nine collections from the air of seven wards denominated by the mumber 5 to 11 were balken. and $95+$ ufd $\mathrm{ml}$. were commed oul of

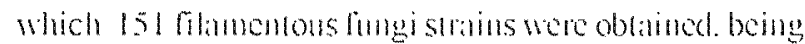
$f(2.65 \%)$ fromwand 5 : $60(3), 73 \%$ ) from wand 6 : $17(11,26 \%$ from ward $7: 18(11.92 \%)$ from ward $8: 19(12.58 \%)$ from wand 9: $7(+.64 \%)$ from ward 10 and $26,(17.22 \%)$ from ward II (Tible 2). In the hospital anitoment the form group

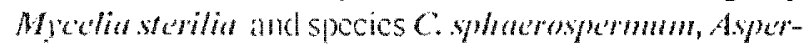
gillassydonit and Codadowpentides, were the nost repre-

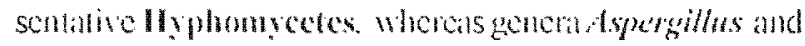
Penicillium representes $+7.7 \%$ of isolations. Suans of species of the generit Anvergillus, Cephaliophora, Claatosporimm. Earoliam, Penicillimm, Phialophora,

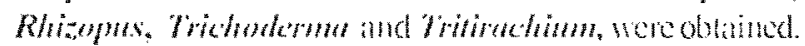
as well as representitics or the order Aphyllophorales and from the form group Mrethu steriliu (Tible 2).

A.sylonit and C.sphaterospermm occurred in six wards: Mycefiat sterilia ind Penicillium

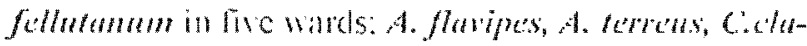
dosponioides, Pa arantiogriscon complex, $P$.

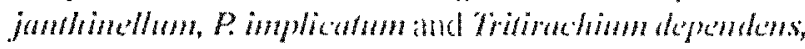

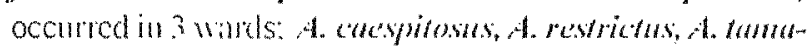
rii, Eurotiun che'salieri, P. decumbens, P. expansum, P. lividum, P. melinii, P. exestrichus and Phiduhphora richardsiat ocurred in 2 wards: strains of order Aphyllophorales and the other species occurred in one ward (Tible2).

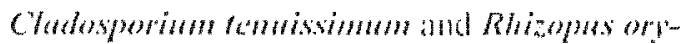
zat. Were isolated trom the sir and from the lloor of enclosed hospital onvirommonis (3): C. ctudespreriondes and $P$.

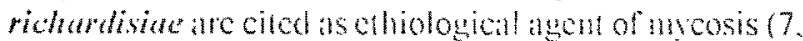

22. 32. 34. 39). The specics C. chatumerimum (13. 14).T.

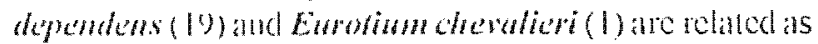
phylopinhogens: the specics P. fellutamum, P. janthinellum, P. anrantiogrisenm complex. P. lividum, $P$. decumbens, Pomelinii, P. restrictmm, Pexpansum, $P$ cilreonigrmm, P. citrinum, P.corylophly hum, P. funiculosum, P.jumezeneskii, P solitum and $P$. thomid oblained in this work, have also been isolated from the air of enclosed hospital cmiromments by Barros ct al. (3). from the soil and dry foodshults (29): Trichoderma peudukoningii is a silprobes found in the soil and recognised as an antagonist of preat potencial (1. 6): among the specics of the order Aphyllophorales than ire siprobes in your majority some species are found parasiting plants (2).

In Ho 113 strains of filamenlous fungi occurred in the elinical and the wards air simples (Table 3). A. sydmit ocured in all clinical samples and in o wards: Mycelia sherilia ocurred in all clinical simples and 5 marts: $C$. sphactespermm in one clinical samples and 6 wards: $P$. ianplicatum in 2 clincal somples and 3 wards $A$. restrictus,

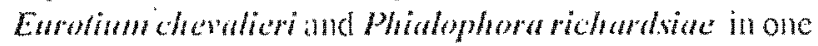
clinicen simple ind 2 wards: Aphyllophorales and others species in one clinical sample and in one ward (Table 3).

These results sugest that propiagules of fungi present in the wards air vary qualitalively and quantibatiscls:

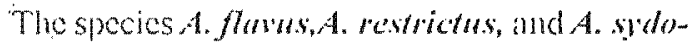
nii aro relaled as pathogenic 10 man and animals (22). A. flawes and A.sydonithere were isolated of the air closed cwirommens of hospitals (3). According to Riper \& Fond (31). A. flawas is fond in the soil and regetable remains and A. sydmit in the soil and humid an.

C. sphatrosperman occurs occisionally in man. in anmals (14. 15). in serenal species of plamis and in the $\operatorname{soil}(1)$

Mycella sterilia is a group of fungi which do not express the capaciny to form spores but have been isolated from regetables and soil. There have been no accounts of the isolation of humbu substracts (2).

P. inthentam was isolated from the air and the noor of enclosed hospital en iromucnts (3). and they have also been isoluted from the soil. and dry foodstuffs and as a resulf of this is considered a biodetoriogenic (29):

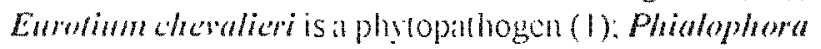
richardsiat is an chiological agen of my cosis $(7,33.35$. (1)).

Allorgy cunsing fungi bolong 10 various gencm and species of which almost all are contaminating and easily isolated from the atmospheric ali (2). According 10 Fartia (15). Heiman (18). Ostathe al (28) and Rippon. (32). Here is a correlation of limgi wilh allergic process becanse 
there is a big amount of allergenic fungi in the air. Allergic processes arose from inhalation of spores, ingestion or through circulating allergens which cause various clinical manifestations (22).

It was not possible to trace a profile of fungi that occurred in the clinical and ward air samples, because the number of patients as wcll as the time of hospitalization of the latter in the wards varied a greal deal. The number of patients changed due to their recovery. In some wards it was not possible to collect air at a single time, because there were no patients in the marked days for two follwing collect. Most of the patients in the matked days for two following collections. Most of patiens were not in the same ward, periods of time ranging from $24 \mathrm{~h}$ and up more than 30 days, depending on clinical state. Consequently, work could not bc accomplished in a scquential order.

Therefore the lesser or the major number of isolated fungi from the ward air, did not represent a lesser or a major frequency of occurrence of the species in the wards.

Table 1.- Filamentous fungi isolated from AIDS patients (University Hospital).

\begin{tabular}{|c|c|c|c|c|c|}
\hline \multirow[b]{2}{*}{ Fungi } & \multicolumn{3}{|c|}{ Clinical samples } & \multicolumn{2}{|l|}{ Total of } \\
\hline & OFS & NS & EES & samples & $\%$ \\
\hline Absidia corymbifera & - & 02 & $=$ & 02 & 2,30 \\
\hline Aphyllophorates & 01 & 03 & 02 & 16 & 6,90 \\
\hline Aspergillus aculeatum & - & 01 & - & 01 & 1,15 \\
\hline A.flavus & - & 01 & - & 01 & 1,15 \\
\hline A.japomicus & - & 02 & - & 02 & 2,30 \\
\hline A.melleus & - & 01 & - & 01 & 1,15 \\
\hline A. niger & - & - & 02 & 02 & 2,30 \\
\hline A. ochraceus & - & 01 & - & 01 & 1,15 \\
\hline A. purasiticus & -" & - & 04 & of & 4,60 \\
\hline A. restrictus & - & - & 03 & 03 & 3,45 \\
\hline A. sclerotiormm & - & 01 & $=$ & 01 & 1,15 \\
\hline A. syrowii & ol & 01 & 01 & 03 & 3,45 \\
\hline A. versicolor & - & $m$. & 01 & 01 & 1,15 \\
\hline Cladosporium sphaerospernum & - & 02 & - & 02 & 2,30 \\
\hline Coprinusspy. & - & 01 & - & 01 & 1,15 \\
\hline Eupenicillum javanicum & - & 01 & - & 01 & 1,15 \\
\hline Eurotium chevalieri & - & 01 & - & 01 & 1,15 \\
\hline Fusarium lateritium? & - & 05 & - & 05 & 5,75 \\
\hline Foxysporam & - & 11 & - & 11 & 12,65 \\
\hline Fisolani & - & 04 & - & 04 & 4,60 \\
\hline Myculia sterilia & 01 & 17 & 02 & 20 & 23,00 \\
\hline Pateilomyces variotî & - & 01 & - & 01 & 1,15 \\
\hline Penicillitm implicatum & - & 01 & 02 & 03 & 3,45 \\
\hline Pestalotiopsis gucpini & - & 01 & - & 01 & 1,15 \\
\hline Phialophora richardsiate & 01 & - & - & 01 & 1.15 \\
\hline Trichoderma harziantm & - & 01 & - & 01 & 1,15 \\
\hline T. komingil & - & 01 & - & 01 & 1,15 \\
\hline To psetudokmingii & - & 01 & - & 01 & 1,15 \\
\hline Verticilliun albo-atrum & - & 01 & - & 01 & 1,15 \\
\hline Volutellat tristis & - & - & 02 & 02 & 2,30 \\
\hline Xyluriat sp. & - & 02 & - & 02 & 2,30 \\
\hline Total & 04 & 64 & 19 & 87 & 100 \\
\hline
\end{tabular}


Table. 2.- Filamentous fungi isolated from the ward añ with AIDS patients in the University Hospital.

\begin{tabular}{|c|c|c|c|c|c|c|c|c|c|}
\hline \multirow[b]{2}{*}{ FUNGI } & \multicolumn{7}{|c|}{ WARDS } & \multicolumn{2}{|l|}{ TOTALOF } \\
\hline & 5 & 6 & 7 & 8 & 9 & 10 & 11 & STRAINS & $\%$ \\
\hline Aphyllophorales & - & - & 01 & - & - & - & - & 01 & 0,66 \\
\hline Aspergillus asperescens & - & 0 & - & - & - & - & - & 01 & 0,6 \\
\hline A. couspitosus & - & 01 & 01 & - & - & - & - & 02 & 1,32 \\
\hline A. cabbonarias & - & 01 & - & - & - & - & - & 01 & 0,66 \\
\hline A. camens & - & 01 & $=$ & - & - & - & - & 01 & 0,60 \\
\hline A. duricandis & - & - & - & - & 01 & - & - & 01 & 0,66 \\
\hline A. flavipes & - & 05 & - & 01 & - & - & 01 & 07 & 4,63 \\
\hline A. flavus & - & - & - & - & 01 & - & - & 01 & 0.66 \\
\hline A. nivens & - & - & 01 & - & - & - & - & 01 & 0.60 \\
\hline A. restrictus & - & 0,3 & - & 02 & - & - & - & 05 & 3,31 \\
\hline A. sydomii & - & 03 & 01 & 02 & 03 & 01 & 03 & 13 & 8,61 \\
\hline A. tommurii & - & - & 02 & - & 01 & - & - & 03 & 1.90 \\
\hline A. torrens & " & 02 & * & 01 & 01 & - & - & 4 & 265 \\
\hline Cephaliophoma tropica & - & 01 & - & - & $=$ & - & - & 01 & 0,60 \\
\hline Chatosporiant cladosporionides & - & 07 & 01 & - & - & - & 02 & 10 & 6,62 \\
\hline C. cuchnorinnm & 04 & - & - & - & - & - & - & 0 & 2,65 \\
\hline C.sphothespermm & - & 10 & 02 & 03 & 02 & 01 & 02 & 20 & 13,24 \\
\hline C. tennissimmm & - & - & * & 01 & - & - & - & 01 & 0,60 \\
\hline Eurotiun chevalieri & - & 01 & " & - & - & $=$ & 01 & 02 & 1.32 \\
\hline Myctia sterilia & - & 07 & 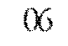 & 01 & - & 01 & 08 & 23 & 15,23 \\
\hline Penicillinn anraniogrisemm & & 01 & - & 01 & 01 & $=$ & $=$ & 03 & 199 \\
\hline P citrofmigrmn & - & * & - & - & 01 & - & - & 01 & 0,66 \\
\hline Pcillinm & - & 01 & - & $=$ & $=$ & $=$ & - & 01 & 0.66 \\
\hline Pconylonghan & - & - & - & " & - & - & 01 & 01 & 0,66 \\
\hline P. decumbens & - & - & - & 01 & - & - & 01 & 12 & 1,32 \\
\hline P. expmbmon & - & .01 & - & - & $0 !$ & - & - & 12 & 1.32 \\
\hline P. fellutumimn & - & 02 & - & 01 & 02 & 02 & 01 & 08 & 5,30 \\
\hline P. funiculosmm & & 01 & - & - & - & - & - & 01 & 0,66 \\
\hline P.jancouneskii & - & - & - & - & - & 01 & - & 01 & $0.6 \times 3$. \\
\hline P.jamthincllum & - & 16 & - & - & 01 & - & 01 & 18 & 5,30 \\
\hline Pimplicatum & - & - & - & 0 & - & (1) & 01 & 03 & 1.99 \\
\hline P.lividum & - & 02 & - & - & 01 & - & - & 03 & 1,99 \\
\hline P.melinit & - & 01 & * & - & 01 & - & - & 02 & 1.32 \\
\hline P. nestrichs & - & - & 01 & * & 01 & - & - & 02 & 1,32 \\
\hline P.solinnm & - & 01 & - & - & - & - & - & 01 & 0,66 \\
\hline P.thomii & - & - & - & - & - & - & 01 & 01 & 0,6 \\
\hline Phalophonte richarisiat & - & 01 & - & 01 & - & - & - & 02 & 1.32 \\
\hline Rhizopuss oryzue & - & - & - & - & - & - & 01 & 01 & 0,66 \\
\hline Tritirachinut dependens & - & - & 01 & 02 & 01 & - & - & (H & 2.65 \\
\hline Trichodema psendokoningii & - & - & - & - & & - & 02 & 02 & 1,32 \\
\hline Total & 14 & 60 & 17 & 18 & 19 & 07 & 26 & 151 & $100 \%$ \\
\hline
\end{tabular}


Table. 3.- Filamentous fungi isolated from AIDS patients and from the ward air in which they were treated (Unisersity Hospital)

\begin{tabular}{|c|c|c|c|c|c|c|c|c|c|c|c|c|c|c|}
\hline \multirow{3}{*}{ FUNGI } & \multicolumn{11}{|c|}{ SAMPLES } & \multirow{3}{*}{ NS } & \multirow{3}{*}{ TS } & \multirow{3}{*}{$\%$} \\
\hline & \multicolumn{3}{|c|}{ CLINICAL } & \multirow[t]{2}{*}{ NS } & \multicolumn{7}{|c|}{ WARDS } & & & \\
\hline & ofs & NS & EES & & 5 & 6 & 7 & 8 & 9 & 10 & 11 & & & \\
\hline Aphyllophorales & - & 06 & - & $\infty$ & - & - & 01 & - & - & - & - & 01 & 07 & 6.78 \\
\hline Aspergillus favus & - & 01 & - & 01 & - & - & - & - & 01 & - & - & 01 & 02 & 1.69 \\
\hline A. restrictus & - & - & 03 & 03 & - & 03 & - & 02 & - & - & - & 05 & 08 & 7.63 \\
\hline A. sydomit & 01 & 01 & 01 & 03 & - & 03 & 0 & 02 & 103 & 01 & 03 & 13 & 16 & 13,56 \\
\hline Cladosporium & & & & & & & & & & & & & & \\
\hline sphaterospernnun & - & 12 & - & 02 & - & 10 & 02 & 03 & 02 & 01 & 02 & 20 & 22 & 21,19 \\
\hline Eurotiam chevalieri & - & 01 & - & 01 & - & 01 & - & - & - & - & 01 & 02 & 03 & 2,54 \\
\hline Mycelia sterifia & 01 & 17 & 02 & 20 & - & 07 & $\infty$ & 01 & - & 01 & 08 & 23 & 43 & 36.4 \\
\hline Penicillium inplicatum & - & 01 & 02 & 03 & - & - & - & ol & - & 01 & 01 & 03 & $\infty 6$ & 5,09 \\
\hline Phialophora & & & & & & & & & & & & & & \\
\hline $\begin{array}{l}\text { richardsiae } \\
\text { Trichoderma }\end{array}$ & 01 & - & - & 01 & - & OI & - & 01 & - & - & - & 02 & 03 & 2.54 \\
\hline psendokoningai & - & 01 & - & 01 & - & - & - & - & - & - & 02 & 02 & 03 & 2.54 \\
\hline Total & 03 & 30 & 08 & 41 & - & 25 & 10 & 10 & 06 & 04 & 17 & 72 & 113 & 100 \\
\hline
\end{tabular}

\section{ACKNOWLEDGMENTS}

financial support.

The authors are grateful to CAPES for

\section{REFERENCES}

1.- Agrios, G. N. (1988), Plant pathology. Sim Diggo: Academo Press. $803 \mathrm{pp}$.

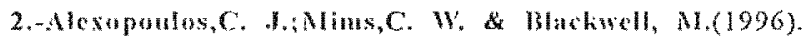
Introdutiony myology folm Whey \& Sme he New Jork $868 \mathrm{pp}$

3.- Manros, G. M.; Qucirom, L. A.; Cavalatuth, M. A. O. (1000). Fungos isolados do ar e do piso de ambientes lectudos do Hospital Escola da Unversidade Federal de Permambuco, Rscife, Brasil - II. . Boletin Mlicologico $5: 69-72$

4.- Batista, A. C.; Lima, A. A.; souma, R. G. (1960). Fungos

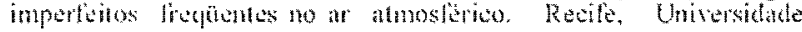
Federal de Pemambuco. Instituto de Nicologia.

5.- Nenaterat, B. \& Unanue, L. R. (1986). Immologit. $2^{2}$ d. Buenos Aires: l'anmericama.

6.- Bergamin Kthu, A.; Kmat, H.; Amonim, I. (1995) Mamal

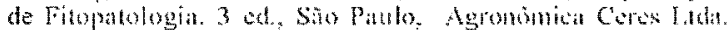

7.- Bossche, 11. V.; Mackeneic, D. W. R.; Canwembergh, s.; $^{2}$ Cutsem, J. W; Drouhet, E; Dupm, 33. (1990). Mycoses in ADS palients. Nes York: Plemom press.

8.- Choi, T. J. (1977). Sindies on the nomal fungal flora in otolarygological field in Korea. In: Second Intemational Mycologieal Congress, Florida.

9.- Del palacio llernandez, A.; Casado, A. V; Lopey, P. Hi; Quiros, 0 . II; Pahancar; P. M. (1989). Opportunistic hung indection by Fratain moniliforme from an ADS patients. Rev. Iber, Whol. $6: 144-147$

10.. De Vita Jr, T, V.; IIellman, S. \& Rasemberg, S. A. (1991). ADS, SIDA efiologia diagnose, tritamento e prevencito. Rio de Ianciro: Revinter.

11.- Domsth, K. If; Gams, W; Anderson, T, I1, (1993). Compendium of soll lingi. San Fonciseo: Academio Press. V.I.

12.- Visenstin, D. J.; Mithinger, 1. W. \& Whotes, J. C. (1990). 


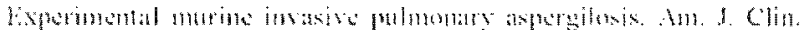
Pathit. $03: 514-515$

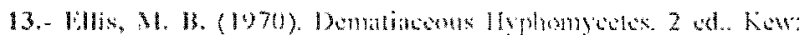
Cimblian Kews

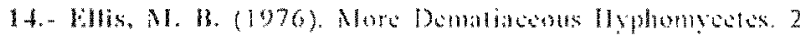
ed. Ken: Combrim News.

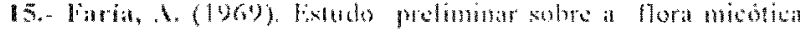

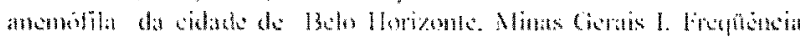

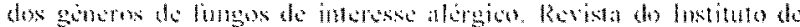

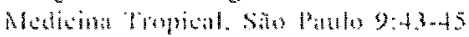

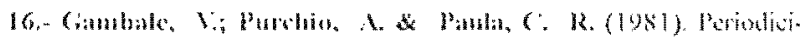

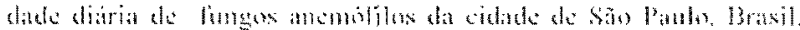

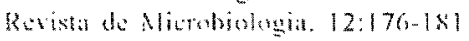

17.- (x)

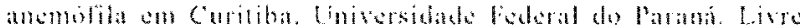
bostritition

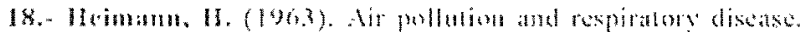

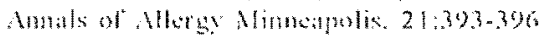

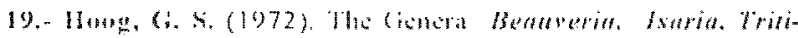

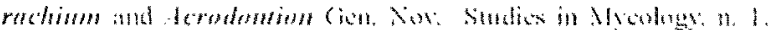

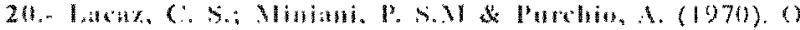

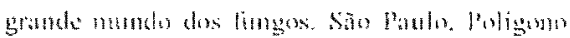

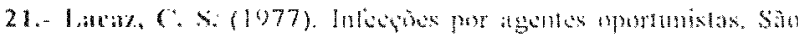
Patolo. Polignow

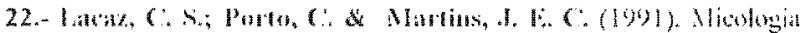

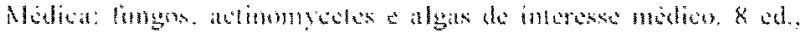

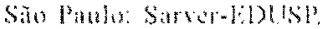

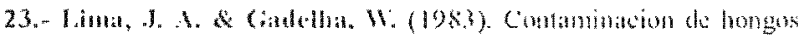

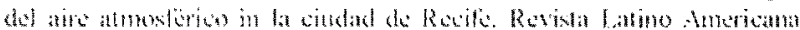
do Nitubinotosit. $25: 243-251$

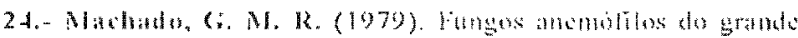

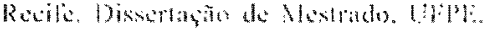

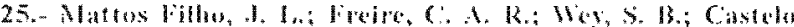

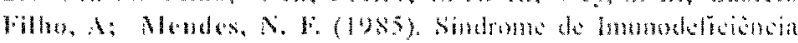

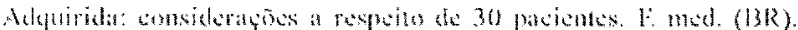
$91: 3.31) \cdot 36$

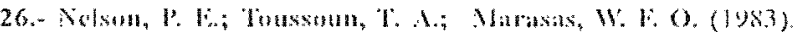

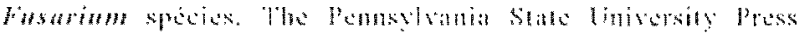
Copsingle

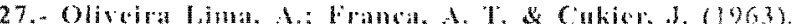

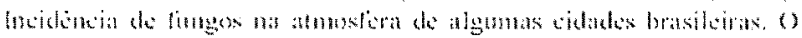

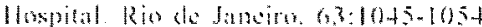

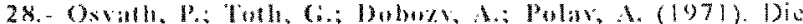

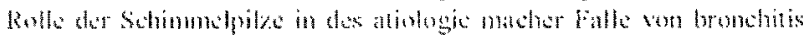

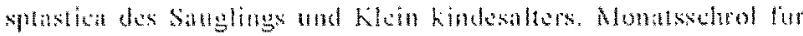

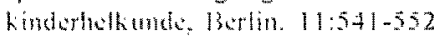

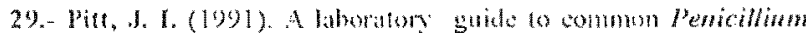

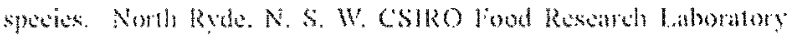

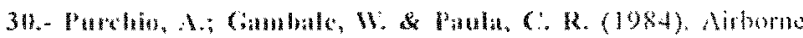

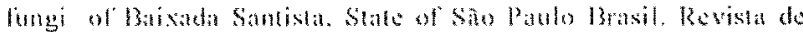

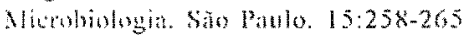

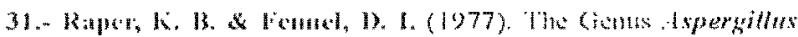

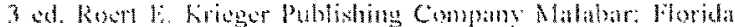

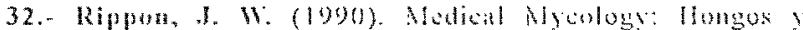

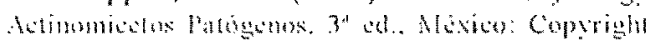

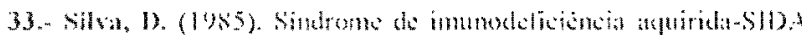

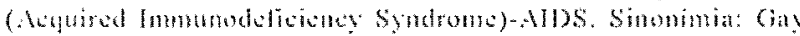
whatrome, llikin Medica $7: 5 \cdot 13$

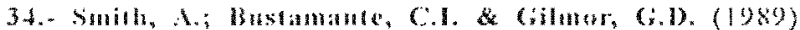

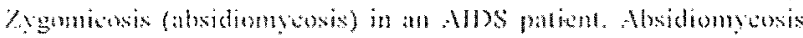

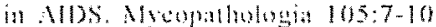

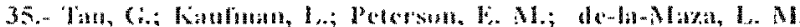

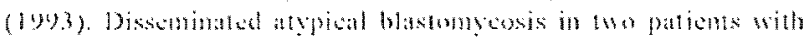
Alls. Clumal Inted. Dis, 16:107.111

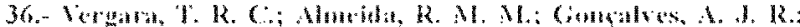

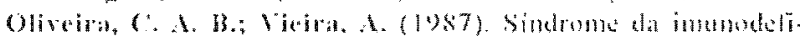

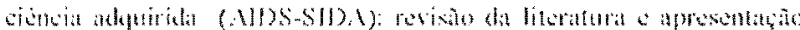

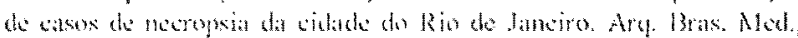
6. $6.6 \mathrm{sin}$

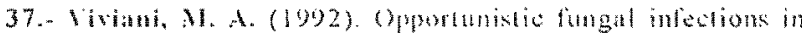

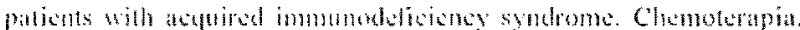
$38: 35-42$

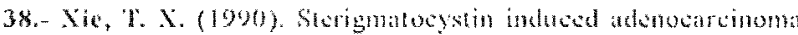

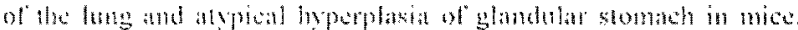

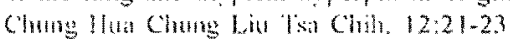

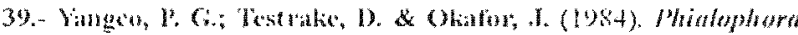

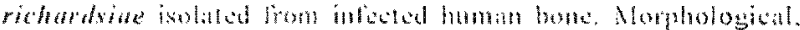

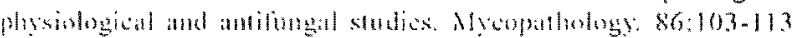

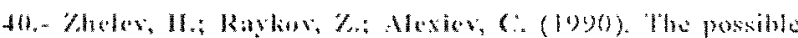

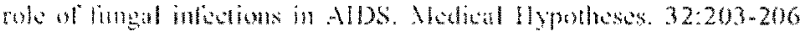

